\title{
Exploring the impact of the Victims' Directive on service provision for victims of crime in Ireland
}

\author{
SUSAN LEAHY
}

AND

EIMEAR SPAIN

University of Limerick

\begin{abstract}
The article considers the impact which the Victims' Directive will have on service provision for victims in Ireland and the challenges which will be faced in seeking to make the objectives of the Directive a reality. The primary focus of the Directive is the provision of effective services to victims of crime 'to ensure that [they] receive appropriate information, support and protection and are able to participate in criminal proceedings'. Unlike proposals to give participatory or procedural rights to victims, providing services such as court accompaniment or similar supports is uncontroversial. However, while these rights are not controversial in principle, ensuring that victims receive consistent and effective services throughout their engagement with the criminal justice process is not necessarily easily achieved. The article begins by discussing the expectations which the Directive creates for victims under each of its three themes; that is, information, support and protection. Within the discussion of each theme, the article will bighlight shortcomings which have been experienced by Irish victims in that area in the past and consider the initial attempts which have been made to meet the Directive's objectives with regard to that specific theme. The authors argue that although clear efforts have been made to ensure the expectations created by the Directive become a reality, Ireland still has some way to go before full compliance is achieved. The article concludes by considering some of the general, practical challenges posed when seeking to implement the level of service provision envisaged by the Directive and outlining the commitments which the state will need to make to ensure that appropriate, Directive-compliant services are provided to victims.
\end{abstract}

Keywords: victims; services; crime; Victims' Directive; service rights; information; support; protection

\section{Introduction}

The primary focus of the Victims' Directive ${ }^{1}$ is the provision of effective services to victims of crime 'to ensure that [they] receive appropriate information, support and protection and are able to participate in criminal proceedings'. ${ }^{2}$ Unlike proposals to give participatory or procedural rights to victims, providing services such as court accompaniment or similar supports is uncontroversial. As Rogan notes: 'alleviating the

1 Directive 2012/29/EU of the European Parliament and of the Council of 25 October 2012 establishing minimum standards on the rights, support and protection of victims of crime, and replacing Council Framework Decision 2001/220/JHA.

2 Article 1(1). 
effects of victimisation is uncontentious'. ${ }^{3}$ However, while these rights are not controversial in principle, ensuring that victims receive consistent and effective services throughout their engagement with the criminal justice process is not necessarily easily achieved. In Ireland, standards for service provision are set out in the Victims' Charter and Guide to the Criminal Justice System (hereafter the Victims' Charter) ${ }^{4}$ which, although not legally binding, imposes obligations on all key criminal justice stakeholders to provide victims of crime with appropriate support. In spite of these guarantees, however, shortcomings in service provision for victims of crime have been repeatedly identified by both research reports and victim representative groups.

The Victims' Directive and the legislation which implements it in Ireland (i.e. the Criminal Justice (Victims of Crime) Act 2017) (hereafter the 2017 Act) will place the obligation to provide effective services to victims on a statutory footing, providing Irish victims with justiciable rights in this area for the first time.The article considers the impact which the Directive will have on service provision for victims in Ireland and the challenges which will be faced in seeking to make the objectives of the Directive a reality. The article begins by discussing the expectations which the Directive creates for victims under each of its three themes, that is, information, support and protection. Within the discussion of each theme, the article will highlight shortcomings which have been experienced by Irish victims in that area in the past and consider the initial attempts which have been made to meet the Directive's objectives with regard to that specific theme. The authors argue that, although clear efforts have been made to realise the expectations created by the Directive, Ireland still has some way to go before full compliance is achieved. The article concludes by considering of some of the general, practical challenges posed when seeking to implement the level of service provision envisaged by the Directive and outlining the commitments which the state will need to make to ensure that appropriate, Directive-compliant services are provided to victims

\section{The promise of the Directive: expectations for service provision post-implementation}

The Victims' Directive sets the bar high for service delivery, imposing clear obligations on member states to provide quality services at all stages of the criminal justice system from initial contact (even if no subsequent formal complaint is made), right through to an offender's eventual release from prison. All criminal justice stakeholders incur responsibilities in this and the state must also ensure that voluntary support organisations are adequately resourced to be able to support victims effectively. 5 Prior to the implementation of the Directive in Ireland, service provision was governed by the Victims' Charter which was originally enacted in 1999 and revised in 2010. Although the Charter imposes key responsibilities on criminal justice stakeholders such as the Gardaí, the Director of Public Prosecutions (DPP) and the courts in relation to service provision, it does not give rise to legally enforceable rights. Consequently, ' $\mathrm{t}$ ] $\mathrm{erming}$ it a charter is perhaps giving it a little too much credit, as it really just sets out existing protections for victims in consolidated format'. ${ }^{6}$ Indeed, the Charter 'acknowledges its own inherent limitations as a tool for instantiating the rights of victims by placing considerable

3 Mary Rogan, 'Victims' Rights: Theory and Practice - Part I' (2006) 24 Irish Law Times 140, 143.

4 Victims of Crime Office, Victims' Charter and Guide to the Criminal Justice System (Department of Justice, Equality and Law Reform 2010).

5 Article 8(3).

6 Mary Rogan, 'Victims' Rights: Theory and Practice - Part II' (2006) 24 Irish Law Times 151, 152-3. 
emphasis on how to make complaints about criminal justice agencies' ${ }^{7}$ Thus, the Directive and the 2017 Act mark a significant development for victims, providing them for the first time with justiciable rights in relation to service provision. In turn, naturally, this places heightened pressures on the state to ensure that these rights are realised.

This section of the article will discuss the level of service provision which victims can expect with the implementation of the Directive in Ireland. Given the space available, it is not possible to discuss the entirety of the Directive here. The article focuses on the rights available to adult victims, ${ }^{8}$ from initial complaint through to the completion of the trial process. For ease of discussion, the services which should be provided will be discussed according to the three themes of the Directive (information, support and protection). The Directive's guarantees under each heading will be outlined and any preexisting shortcomings in service provision under each heading will be highlighted. Moreover, initial attempts to realise the expectations created by the Directive under each theme will be discussed and critiqued.

\section{Information}

Providing information to victims as they journey through the criminal justice process is vital. Ensuring that victims are aware of developments in the investigation and trial of an offence empowers them, minimising the potential for secondary victimisation which can arise when they feel isolated in their journey through the criminal justice system. At a more practical level, effective information provision ensures that victims are aware of available supports and protections which they are entitled to. As noted by the EU Agency for Fundamental Rights:

Lack of information not only represents a serious obstacle to the enjoyment of victims' rights, but research on victim satisfaction with support services has also repeatedly identified the lack of information as a prime source of dissatisfaction with criminal proceedings, and one which discourages them from actively participating. 9

The Victims' Directive places obligations on member states to ensure that victims receive appropriate information at the initial reporting stage (Article 4) and in relation to the progress or otherwise of the case (Article 6). Each Article is discussed here in turn, with reference to Ireland's efforts to comply with the requirements set by them.

\section{ARTICLE 4: RIGHT TO RECEIVE INFORMATION FROM THE FIRST CONTACT WITH A COMPETENT AUTHORITY}

Article 4 provides that:

Member States shall ensure that victims are offered the following information, without unnecessary delay, from their first contact with a competent authority in order to enable them to access the rights set out in this Directive:

7 Lillian McGovern, 'The Victim and the Criminal Justice System' in Paul O'Mahony (ed), Criminal Justice in Ireland (Institute of Public Administration 2002) 393, 398.

8 Specific protections provided for child victims in the Directive will not be discussed here. For the purposes of the Directive, 'victim' includes 'a natural person who has suffered harm, including physical, mental or emotional harm or economic loss which was directly caused by a criminal offence' and 'family members of a person whose death was directly caused by a criminal offence and who have suffered harm as a result of that person's death': Article 2(1)(a). In relation to the latter category, 'family members' includes 'the spouse, the person who is living with the victim in a committed intimate relationship in a joint household and on a stable and continuous basis, the relatives in direct line, the siblings and the dependents of the victim': Article 2(1)(b).

9 EU Agency for Fundamental Rights, Victims of Crime in the EU: The Extent and Nature of Support for Victims (EU Agency for Fundamental Rights 2014) 49. 
a) the type of support they can obtain and from whom, including, where relevant, basic information about access to medical support, any specialist support, including psychological support, and alternative accommodation;

(b) the procedures for making complaints with regard to a criminal offence and their role in connection with such procedures;

(c) how and under what conditions they can obtain protection, including protection measures;

(d) how and under what conditions they can access legal advice, legal aid and any other sort of advice;

(e) how and under what conditions they can access compensation;

(f) how and under what conditions they are entitled to interpretation and translation;

(g) if they are resident in a Member State other than that where the criminal offence was committed, any special measures, procedures or arrangements, which are available to protect their interests in the Member State where the first contact with the competent authority is made;

(h) the available procedures for making complaints where their rights are not respected by the competent authority operating within the context of criminal proceedings;

(i) the contact details for communications about their case;

(j) the available restorative justice services;

(k) how and under what conditions expenses incurred as a result of their participation in the criminal proceedings can be reimbursed.

Given their central role in receiving complaints and investigating offences, the Gardaí are the organisation which bears the primary responsibility for providing victims with the information outlined in Article 4. The Victims' Charter imposes substantial obligations on the Gardaí to provide information to victims. When a victim makes a complaint, s/he must be informed of 'the name, telephone number and station of the investigating Garda and the PULSE incident number'. ${ }^{10}$ The Gardaí must '[e]xplain what will happen and keep [the victim] informed of the criminal investigation' and '[t]ell [the victim] in writing about the crime victims helpline ${ }^{11}$ and the other services available for victims', ${ }^{12}$ as well as providing victims with specific information when a suspect in due to appear in court. ${ }^{13}$ Thus, the obligations to provide information outlined in the Directive were already required in Ireland, albeit not on a statutory basis. However, despite the obligations in the Charter, the provision of information to victims by the Gardaí has been repeatedly found wanting.

Information is formally communicated to victims by the Gardaí via standardised victim letters that are generated by the PULSE system. ${ }^{14}$ The first letter empathises with the victim and provides the PULSE reference number, the investigating Garda's name and the Garda

10 A PULSE (i.e. police using leading systems effectively) incident number is the unique computer-generated number which is allocated to an incident on the Garda computer system.

11 Victims of Crime Office (n 4) 16.

12 Ibid.

13 The information to be provided included: whether the suspect is being held in prison or is on bail (and any conditions which attach to bail); the time, date and location of the court hearing; details of the prosecution process, including information about support which is available from voluntary organisations in relation to attendance at court (e.g. accompaniment services); whether a victim impact statement is possible; and the final result of the trial: ibid.

14 Garda Inspectorate, Report of the Garda Siochana Inspectorate: Crime Investigation (Garda Inspectorate 2014) Part 7, 4. 
station contact number, as well as the contact details for the crime victims' helpline. ${ }^{15} \mathrm{~A}$ leaflet with the contact details of other support organisations is also enclosed. ${ }^{16}$ The second letter will be sent once an offender is identified and the case has progressed. ${ }^{17}$ Presumably, in some cases, these letters will be supplemented with informal updates from investigating Gardaí as and when appropriate. However, despite these processes, the Gardaí have not been consistent in delivering information to victims. For instance, in a study of victims' experiences in the criminal justice system conducted in 2010:18

Roughly 1 in 10 of the respondents who reported a crime indicated that they did not receive the name of the Garda to whom they reported the crime; 1 in 5 claimed not to have received the contact details of the investigating Garda; 1 in 2 claimed not to have received the pulse incident number; 1 in 2 claimed not to have received a contact for a group supporting victims; and only 4 in every 10 respondents who reported the crime indicated that they received the number for the [crime victims' helpline]. ${ }^{19}$

Based on their interviews with victims in that study, the researchers found that for victims, 'the lack of information was evidence of a lack of respect, demonstrated that they were not being taken seriously, and acted as a further burden'. ${ }^{20}$ Thus, the 'information gap' results in more than an inconvenience and can create significant distress for victims. The Garda Inspectorate has also identified deficiencies in Garda provision of information to victims. In a review of letters sent to victims in the third quarter of 2013, the inspectorate found that just over 3000 victims did not receive the first standardised letter and just over 1500 did not receive the second. ${ }^{21}$ The inspectorate expressed disappointment that there was 'little or no evidence of supervisors contacting victims of crime to determine the levels of service provided'. ${ }^{22}$ In 43 per cent of the cases investigated by the inspectorate, there were no updates on PULSE in the 12 months that followed the creation of the record. ${ }^{23}$ Consequently, the inspectorate concluded that there was 'an inconsistent approach to updating victims and there was no national standard as to how or when this contact should take place other than the two required victims letters'. ${ }^{24}$ Most recently, in the Garda Public Attitudes Survey 2015, of the 682 respondents who were victims of crime, only 34 per cent were given a PULSE number and just 33 per cent were given the number of victim helplines and services. ${ }^{25}$

It is clear then that the efforts of the Gardaí to ensure that victims' entitlements to information are realised have not been entirely successful to date. The Act places statutory obligations on the Gardaí to deliver information to victims. Section 7 creates a list of information which must be offered to victims upon first contact with the Gardaí

15 The crime victims' helpline is a 'confidential national helpline run by a team of trained volunteers'. The helpline supports all victims, regardless of when the crime took place, who committed it or whether or not it has been reported to the Gardaí: Victims of Crime Office (n 4) 13.

16 Ibid.

17 Ibid, 5.

18 This study involved a postal survey of approximately 1050 victims who had availed of a victim support service: Shane Kilcommins, Máire Leane, Fiona Donson, Caroline Fennell, Anna Kingston, The Needs and Concerns of Victims of Crime in Ireland (Commission for the Support of Victims of Crime 2010) 10.

19 Ibid 45.

20 Ibid 55.

21 Garda Inspectorate (n 14) Part 7, 5.

22 Ibid 6.

23 Ibid 11.

24 Ibid.

25 An Garda Síochána, An Garda Siochána Public Attitudes Survey (An Garda Síochána 2015) 11. 
regarding an alleged offence. This includes information about: support services; formal complaint procedures; where to direct queries relating to the complaint; availability of interpretation and translation services; the role of the victim in the criminal justice process; special measures available for victims who are residents of the state or for child victims; availability of protection measures and/or compensation; a victim's right to make a victim impact statement; complaints procedures where entitlements under the legislation are not honoured; restorative justice (where available); availability of legal aid; and entitlement to expenses. ${ }^{26}$ The extent and detail of the information offered will be determined on a case-by-case basis with reference 'to the type or nature of the alleged offence and any specific needs and personal circumstances of the victim which are identified'. ${ }^{27}$ Where a victim requests any of the information offered under s $6, \mathrm{~s} /$ he may specify whether the information should be provided orally or in writing (including by electronic means) and s/he shall be provided with the information as soon as practicable and where possible, in the manner specified in his/her request. ${ }^{28}$

In an effort to ensure that the obligations imposed in the Directive and the forthcoming legislation are met, in December 2015 the Gardaí introduced 28 Victim Service Offices, one in each Garda Division. Staffed by specially trained Gardaí, the offices are open Monday to Friday from 9am to $5 \mathrm{pm}$. Victims can choose between receiving contact by phone, letter or email. The central role of these offices is to keep victims informed of all significant developments associated with their case and to provide contact details for relevant support/counselling services. Victims receive a follow-up call from the Victim Service Office to ensure they have all the information they require including contact details of the investigating Gardaí. Victims can also raise any problems or concerns they have in the wake of the crime or issues with the investigation. They will be provided with crime prevention advice and details for external support services. ${ }^{29}$

Importantly, the Gardaí are committed to monitoring victim satisfaction with their service provision through their quarterly Public Attitude Survey and engagement with victims and their representative groups. An upgrade of the PULSE system is also promised which will record more details about victims' needs, as well as 'enhanced functionality in relation to the printing of letters to victims of crime including two additional letters' ${ }^{30}$ It is too early to assess whether the foregoing efforts are sufficient to ensure that the victims' rights under Article 4 are effectively realised. However, initial reactions are positive. For example, the crime victims' helpline has recorded a 'notable decrease in calls to the helpline where the caller in unable to make contact with the investigating Garda'. ${ }^{31}$ The Gardaí have thus clearly made a concerted effort to honour their obligations under the Directive. Nevertheless, given the shortcomings which have been identified with information provision in the past, it is important not to become complacent, especially now the Act is commenced and the duty to provide information has become a legal obligation. The Gardaí must continue to monitor and evaluate their

\footnotetext{
$26 \mathrm{~S} 7(1)$.

$27 \mathrm{~S} 7(2)$.

$28 \mathrm{~S} 7(3)$.

29 It is noteworthy that victims of crimes where there is significant trauma such as sexual crimes or domestic abuse will continue to be dealt with in person by an investigating or specialist Garda.

30 Anne-Marie McMahon, 'Putting Victims at the Heart of Garda Service', presentation delivered at Victims in Focus: European and Domestic Perspectives, Association for Criminal Justice Research and Development Annual Conference (2 October 2015).

31 Crime Victims' Helpline, Annual Report 2015 (Crime Victims Helpline 2016) 1.
} 
information provision and develop their protocols so that victims are kept adequately informed at all stages of the criminal justice process.

\section{ARTICLE 6: RIGHT TO RECEIVE INFORMATION ABOUT THEIR CASE}

Article 6 provides victims with the right to receive information about:

(i) any decision not to proceed with or to end an investigation or not to prosecute the offender; 32

(ii) the time and place of the trial and the nature of the charges against the offender; ${ }^{33}$

(iii) any final judgment in a trial; ${ }^{34}$ and/or

(iv) information enabling the victim to know about the state of the criminal proceedings, unless in exceptional cases the proper handling of the case may be adversely affected by such notification. ${ }^{35}$

The Victims' Charter imposes the primary obligation of delivering this information on the Gardaí. ${ }^{36}$ Thus, the shortcomings which have been identified in relation to information provision by the Gardaí would apply to this category of information also. For example, when victim respondents to the Garda Attitudes Survey 2015 were asked for their views on the information provided regarding the progress of the investigation, although 46 per cent felt it was 'about right', 36 per cent felt that it was 'too little' and 16 per cent were not provided with updates. ${ }^{37}$ Section 8 of the Act provides that all of the foregoing information and more can be requested from the Garda Síochána, the Ombudsman Commission, the DPP, the Irish Prison Service, the director of a children detention school or the clinical director of a designated centre, as the case may be. ${ }^{38}$ Thus, the Gardaí now have a statutory obligation to provide this information, a duty which will be discharged through use of the Victim Service Offices and changes to the PULSE system discussed above.

Perhaps one of the most significant pieces of information covered by Article 6 is the provision of reasons for a decision not to prosecute. Given the upset experienced by a victim when their case is not prosecuted, effective communication about this decision is crucial to avoid secondary victimisation. ${ }^{39}$ For less serious offences, such as minor assaults or public order offences, the Gardaí make the decision on whether to prosecute and will prosecute the offence in the name of the DPP. Victims can request a summary of reasons for the decision of the Gardaí not to prosecute. Forms for this request are available on the Garda website. The application must be made within 28 days of the victim finding out that prosecution will not take place and must be sent to the relevant superintendent. For all other prosecution decisions, an application for reasons for a decision not to prosecute must be made to the DPP. The Victims' Charter provides that the DPP will provide reasons for decisions in fatal cases which occurred on or after October 2008. ${ }^{40}$ With the implementation of the Directive on 16 November 2015, this

32 Article 6(1)(a).

33 Article 6(1)(b).

34 Article 6(2)(a).

35 Article 6(2)(b).

36 Victims of Crime Office (n 4) 16.

37 Ibid.

38 S 8(2). S 8(1) provides that the Gardaí or the Ombudsman Commission must inform victims of their right to request this information.

39 Victims who are not satisfied with these reasons can request a review of the decision. This right is guaranteed by Article 11 of the Directive and s 10 of the Act.

40 Victims of Crime Office (n 4) 30. 
facility was extended to all offences. ${ }^{41}$ Victims or the families of victims in fatal cases can obtain a summary of reasons for a decision not to prosecute upon completion of a 'request for reasons' form. ${ }^{42}$ The request must be sent within 28 days of the date the victim is informed of the decision not to prosecute. ${ }^{43}$ A summary of reasons should be provided in writing within 28 days. ${ }^{44}$ The right to request reasons for a decision not to prosecute and a summary of reasons for the decision is placed on a statutory footing by the Act. ${ }^{45}$

In the period from October 2008 (i.e. the introduction of the policy on giving reasons for decisions not to prosecute in fatal cases) to November 2015, 97 requests for reasons were made. ${ }^{46}$ Ninety-two of these requests were granted. Predictably, when the facility to ask for reasons not to prosecute was extended to all crimes in November 2015, the number of requests increased considerably. Between November 2015 and June 2016, 333 requests for reasons were made with reasons being given in 216 cases. ${ }^{47}$ Thus, it seems that, with regard to informing victims about the reasons for the non-progression of their cases, the Office of the DPP has been very progressive in seeking to meet its obligations. The provision of information in a timely manner is also likely to be furthered by the specialised Communications and Victims Liaison Unit which was established by the DPP in July 2015 to ensure that the office meets its obligations under the Victims' Directive. ${ }^{48}$ The Unit provides information to victims and deals with requests for reasons not to prosecute and for reviews of decisions. ${ }^{49}$

The Office of the DPP has been particularly proactive in seeking to meet its obligations under the Directive, forging ahead and implementing changes to the 'reasons for decisions' procedure even before this was required by national legislation. As the figures above illustrate, extending the facility to receive reasons for decisions to all crimes has already led to an increase in requests, thereby increasing the workload for the Office. This burden is likely to increase further now the Act has commenced and more victims become aware of their rights in this area. Consequently, resource implications are likely to arise which must be dealt with to ensure the Office continues to meet its obligations and that victims' rights are realised. What is also significant to ensure effective service delivery in this area is considering how information about reasons is delivered. A decision not to prosecute is typically based on the insufficiency of evidence in the case (i.e. there is no reasonable prospect of securing a conviction) and/or the fact that it is not in the public interest to prosecute (i.e. because the case is unlikely to be successful). ${ }^{50}$ It is important that victims' expectations are managed so that when they receive what may

41 The DPP cannot provide a summary of reasons where a suspect was dealt with under the Garda Síochána Adult Caution Scheme or the Juvenile Diversion Programme or where the information would: interfere with an ongoing criminal investigation; prejudice a future court case; or jeopardise the personal safety of any person or the security of the state: Office of the DPP, How to Request Reasons and Reviews (Office of the DPP) 3. These limitations are included in $\mathrm{s} 10$ of the Act.

42 This is available on the DPP's website or from Garda stations: Office of DPP (n 41) 4.

43 This time period might be extended 'if there is good reason and if it is in the interests of justice': ibid 5.

44 If this period is to be extended, the victim will be informed in writing that it may take longer to release the information and provided with an indication of when this information may be available: ibid 6 .

$45 \mathrm{~S} 8(2)(\mathrm{d})$.

46 Office of the DPP, Annual Report 2015 (Office of the DPP 2016) 25.

47 Examples of instances where requests are refused would include requests relating to decisions made prior to 16 November 2015, or where giving a reason may prejudice a future court case.

48 Office of the DPP (n 46) 24.

49 The Unit also provides booklets on both these topics on its website.

50 See Office of the Director of Public Prosecutions, Guidelines for Prosecutors (4th edn, Office of the DPP 2016) ch 4. 
appear to be sterile or generic responses to their request for reasons, they will not be unduly disappointed. To optimise service delivery in this area, it will be necessary to collect qualitative data on victims' perceptions of the reasons they are receiving. This will allow the DPP to monitor whether the information is being delivered effectively and serving to meet victims' expectations of the process as far as possible. If victims' expectations of the process are found to be unrealistic, for example, expecting access to information which cannot be disclosed, it is important that appropriate methods of managing victims' expectations are devised. Thus, whilst significant strides have been made in this area of service provision, victims' satisfaction levels and the extent to which this process can deliver the results which victims might expect have yet to be explored.

\section{Support}

The journey through the criminal justice system can be both daunting and traumatic for victims of crime. Appropriate supports are essential so that victims receive assistance where necessary to assist them in participating in the investigation and trial of the offence and, above all, to recover from the harm which they have suffered. Article 8(1) of the Directive provides that: 'Member States shall ensure that victims, in accordance with their needs, have access to confidential victim support services, free of charge, acting in the interests of the victims before, during and for an appropriate time after criminal proceedings.' Member states are obliged to 'facilitate the referral of victims, by the competent authority that received the complaint and by other relevant entities, to victim support services'. ${ }^{51}$ Access to such services cannot be dependent on a victim making a formal complaint. ${ }^{52}$

A full discussion of the myriad of supports for victims which are provided by nongovernmental victim support groups is outside the scope of this piece. Instead, the primary focus of discussion will be on supports provided by state agencies at both the investigation and trial stages of the criminal process. At investigation stage, the Gardai provide a number of supports for victims who might be particularly vulnerable. Specialist family liaison officers (FLOs) are available to support and maintain contact with the families of homicide victims. ${ }^{53}$ These officers can also be appointed in other cases where the Garda District Officer deems it appropriate. ${ }^{54}$ For victims for whom English is not their first language, free translation services are provided by the Gardai. ${ }^{55}$ Finally, there is special provision for members of the LGBT community who may be referred to an LGBT liaison officer and for victims of racist incidents who may have the support of ethnic liaison officers (ELOs). Access officers are also available for victims with disabilities to assist and guide them in surmounting any obstacles which they might face in accessing Garda services.

At trial stage, a key support for victims is preparing them for what will happen in court. The pre-trial meeting with the prosecution legal team is particularly important. Naturally, any interaction between the prosecution lawyers and the victim must be limited as the lawyers cannot be seen to be 'coaching' a witness. However, '[w] hile the evidence or content of the case is not discussed the victim is made aware of the form of the

51 Article 8(2).

52 Article 8(5).

53 Victims of Crime Office (n 4) 17. There are 474 trained FLOs: Garda Inspectorate (n 14) 30.

54 McMahon (n 30).

55 Victims of Crime Office (n 4) 18. 
proceedings, the courtroom and the proximity they will have to the accused'. ${ }^{56}$ The Rape Crisis Network of Ireland has praised the introduction of meetings between representatives of the DPP and victims, noting that this process (which includes a tour of the courts) 'though very simple ... has a profound effect on victims and has been very helpful in alleviating fear of unknown surroundings and procedures' ${ }^{57}$ Such meetings are 'extensively held'. ${ }^{58}$ However, while victim advocates have reported that these meetings are very effective, particularly in the Courts of Criminal Justice in Dublin, some inconsistencies in the quality of the meetings were reported in other parts of the country. ${ }^{59}$ Moreover, although victims of any crime can request a meeting with the prosecution lawyers and the DPP will attempt to facilitate it, if possible such meetings are only offered in cases involving violent or sexual offences. Grozdanova and de Londras found that it was not clear that victim advocates knew that victims could request a meeting with a representative of the Office of the DPP where they were not automatically entitled to one. Thus, greater clarity about this procedure may be required to ensure that victims have full access to this service.

Once the trial begins, court accompaniment is an essential service for victims, providing them with support and a source of information throughout the trial which can be a very confusing and traumatic process. One of the main providers of court accompaniment is Victim Support at Court (VSAC). ${ }^{60}$ This independent voluntary organisation is dedicated solely to supporting victims in court and also organises pre-trial court visits for victims and their families to familiarise them with the court setting before the trial. VSAC provides assistance in trials 'involving criminal offences including murder, manslaughter, death by dangerous driving, attempted murder, rape, sexual assault, harassment, human trafficking, robbery, aggravated burglary, theft arson and tiger kidnappings'. ${ }^{61}$ Kilcommins et al found that court accompaniment is an important means of minimising the negative impact of a victim's experience of court'. ${ }^{62}$ Of the 96 respondents who had used court accompaniment services, 92 stated that they were very satisfied or satisfied with the level of support received from support organisation personnel. ${ }^{63}$ Thus, it is clear that court accompaniment can significantly minimise the potential for victims to suffer secondary victimisation within the court process and it is a very important service for victims.

Although supporting victims is extremely important to help them as they journey through the criminal justice process, ensuring that they have the appropriate opportunity to heal and to participate in the investigation and trial of the offence, there is very little attention paid to this theme of the Directive in the 2017 Act. Section 7(9) provides that on first contact with Gardaí, where the victim consents, arrangements can be made 'for

56 Rumyana Grozdanova and Fiona de Londras, Protecting Victims' Rights in the EU: The Theory and Practice of Diversity of Treatment during the Criminal Trial, National Report: Ireland (Institute of Advanced Legal Studies 2013) 11.

57 Irish Council for Civil Liberties, A Better Deal: The Human Rights of Victims in the Criminal Justice System (Irish Council for Civil Liberties 2008) 18.

58 Grozdanova and de Londras (n 56) 11.

59 Ibid.

60 A number of other specialist victim support groups also offer court accompaniment, including: Children at Risk Ireland which offers support to child victims; Rape Crisis Centres; and OneinFour which offers support to victims of sexual violence; and Women's Aid and ADAPT which offer support to victims of domestic abuse.

61 VSAC Leaflet.

62 Kilcommins et al (n 18) 143.

63 Ibid. 
the victim to be referred to an appropriate, and where relevant specialist, service which provides support to victims'. However, aside from this, support services, whether offered by state or non-state actors receive scant attention in the proposed legislation. Significantly, no commitment is made to adequately fund support services to make sure that appropriate levels of support are available to meet the increased demand for services which will no doubt arise now that the Directive is fully operative in Ireland. The legislature probably shied away from making a commitment like this in the legislation due to the level of resourcing required. Given economic and budgetary constraints, choices may inevitably have to be made about the level of funding which is available for support services at any given point in time. However, it is important, even at policy level, that a commitment is made to adequately resource support services as these are integral to aiding victims during the criminal justice process and in helping them to heal from the trauma of victimisation.

\section{Protection}

Having already been traumatised by victimisation, engagement with the criminal justice process can be very intimidating for victims. This is especially true for particular categories of victims, for example, victims of sexual or domestic abuse, families of victims of homicide or victims who may face intimidation or reprisal for engaging with the criminal justice system. Chapter 4 of the Directive provides for 'protection of victims and recognition of victims with specific protection needs'. Article 18 places an obligation on member states to:

... ensure that measures are available to protect victims and their family members from secondary and repeat victimisation, from intimidation and from retaliation, including against the risk of emotional or psychological harm, and to protect the dignity of victims during questioning and when testifying.

The Directive envisages two levels of protection for victims of crime. They are: general protection which is available for all victims; and special protective measures which are available for victims who are assessed and found to have special protection needs. At a general level, Article 20 provides that during criminal investigations, states must ensure that:

(a) interviews of victims are conducted without unjustified delay after the complaint with regard to a criminal offence has been made to the competent authority;

(b) the number of interviews is kept to a minimum and interviews are carried out only where strictly necessary for the purposes of the criminal investigation;

(c) victims may be accompanied by their legal representative and a person of their choice, unless a reasoned decision has been made to the contrary;

(d) medical examinations are kept to a minimum and are carried out only where strictly necessary for the purposes of the criminal proceedings.

These measures represent best practice for the protection of victims during the investigation stage of the criminal process. It is likely that Gardai adhered to these principles before they were formally obliged to do so. However, these best practice principles are elevated to legislative obligations by s 14 of the Act. Section 14(1) provides that a Garda investigating an alleged offence must ensure that:

(a) where a victim ... is a resident of a Member State other than the State, the victim may make a statement immediately after the complaint is made or at such other time as may be agreed with the victim,

(b) any interviews of a victim that may be required in respect of a complaint are carried out as soon as practicable after the complaint is made, and 
(c) interviews of the victim are carried out only where necessary for the purpose of investigating the alleged offence.

Section 14(6) provides that any medical examinations of a victim 'are limited to those which are strictly necessary for the purpose of the investigation concerned'. Further, the Act provides that victims are entitled to be accompanied by a person of their choice, including their legal representatives, when making a complaint ${ }^{64}$ and during investigation interviews. ${ }^{65}$ This will only be denied where the presence of the chosen person or legal representative would be contrary to the best interests of the victim or would prejudice any investigation or criminal proceedings regarding an alleged offence. ${ }^{66}$ Where a decision is taken to exclude a person from accompanying a victim, s/he may be accompanied by another person and may make such arrangements as are necessary to be so accompanied. ${ }^{67}$

These new requirements to protect victims during criminal investigations may require some changes to how Gardaí approach statement-taking and interviews, but they will ensure best practice in this aspect of investigations. Allowing victims to have accompaniment when being interviewed will be a great source of support and may well encourage victims to stay the course with an investigation where they might otherwise have been too intimidated to continue. Minimising the number of interviews and ensuring that they take place in a timely manner also diminishes the potential for secondary victimisation where victims are forced to relive an incident unnecessarily and/or after a considerable amount of time has passed since the incident occurred. All of these measures also benefit the Gardaí as timely interviews with victims who are comfortable because they are supported by a person of their choice will lead to the collection of better evidence.

At trial, an important general protection for victims is avoidance of contact with the accused. Article 19(1) provides that conditions must be established 'to enable avoidance of contact between victims and their family members, where necessary, and the offender within the premises where criminal proceedings are conducted, unless the criminal proceedings require such contact'. Member states are obliged to ensure that 'new court premises have separate waiting areas for victims'. ${ }^{68}$ Such protection is highly significant for victims. As Mulkerrins notes: '[e]vidence of low-grade intimidation abounds where complainants have to share waiting/cloakroom facilities with the defendant and his family while awaiting hearings'. ${ }^{69}$ Under the Victims' Charter, the Courts Service has committed to aiding victims in avoiding contact with offenders, providing that customer liaison officers can arrange access to victim rooms. ${ }^{70}$ The Charter also provides that a dedicated suite of four rooms and a reception area for victims is available within the Criminal Courts of Justice in Dublin and that waiting rooms are available in 'almost all refurbished courthouses and also in a number of other courthouses'. ${ }^{71}$ Moreover, the

$64 \mathrm{~S} 12(1)$.

$65 \mathrm{~S} 14(2)$.

$66 \mathrm{~S} 12(2)$ and $14(3)$.

67 S 12(3) and s 14(4). A record must be kept of any decision to exclude a person from accompanying a victim pursuant to s $12(2)$ or $14(3)$ and this record must include reasons for the decision: s $12(4)$ and $14(5)$ respectively.

68 Article 19(2).

69 Kate Mulkerrins, 'Trial Venue: The Victim and the Accused' (2003) 3(1) Judicial Studies Institute Journal 120, 127.

70 Victims of Crime Office (n 4) 24. It is also possible to reserve family seating in murder and manslaughter cases: ibid.

71 Ibid. 
Charter makes a commitment that 'rooms will be set aside for victims in all future refurbishment projects'. ${ }^{72}$

Despite these promises, effectively protecting victims from contact with offenders in court has proved difficult to deliver in Ireland because of the structure of many court buildings. Kilcommins et al's study reported that the architecture and design of court facilities is not 'fit for purpose'. ${ }^{73}$ Of 141 relevant responses to a question in the survey on the issue of access to a separate waiting room, only 27 per cent of respondents reported access to this facility. ${ }^{74}$ Recommendations have been made for improvements in this area ${ }^{75}$ and it is clear that this is needed, but this facility is challenging for the Courts Service to deliver. Many Irish courthouses are antiquated and given the volume of cases being dealt with each day, overcrowding is a persistent problem. Admittedly, ensuring that victims are afforded separate waiting facilities in all cases would require major refurbishment of existing courthouses which is resource-intensive, but, to protect victims appropriately, this investment in appropriate facilities for victims in all court buildings is necessary. Unsurprisingly, given the significant resource implications and practical obstacles involved, the Act does not contain a commitment to provide separate waiting areas in courts. Thus, it is likely that this aspect of the Directive's requirements will continue to be unmet in Ireland for the immediate future. Given the trauma experienced by victims when facing defendants and their families in courts, some attempt to overcome these structural and resource issues to find a means of separating victims and defendants during the trial process ought to be considered.

Aside from the general protections that are available for all victims, the Directive also envisages that some victims, because of their characteristics or the nature of the crime, may require additional protective measures. Consequently, the Directive requires member states to:

... ensure that victims receive a timely and individual assessment . . . to identify specific protection needs and to determine whether and to what extent they would benefit from special measures in the course of proceedings ... due to their particular vulnerability to secondary and repeat victimisation, to intimidation and to retaliation. ${ }^{76}$

This assessment must focus on: (a) the personal characteristics of the victim; (b) the type or nature of the crime; and (c) the circumstances of the crime. ${ }^{77}$ The wishes of the victim must also be considered. ${ }^{78}$ If a victim is judged to have special protection needs, special measures are available both during the investigation and during the trial. In relation to the latter, the protective measures available would be classed primarily as procedural or legal rights, providing victims with access to facilities such as giving evidence via television link or from behind a screen or measures to prevent unnecessary questioning about a victim's

72 Ibid.

73 Kilcommins et al (n 18) 127.

74 Ibid.

75 For example: Ivana Bacik, Liz Heffernan, Patricia Brazil and Marguerite Woods, Report on Services and Legislation Providing Support for Victims of Crime (Commission for the Support of Victims of Crime 2007); Irish Council for Civil Liberties, A Better Deal: The Human Rights of Victims in the Criminal Justice System (Irish Council for Civil Liberties 2008).

76 Article 22(1).

77 Article 22(2). Victims must also be closely involved in such assessments and their wishes should be taken into account: Article 22(6).

78 Article 22(6). 
private life. ${ }^{79}$ Since the focus of discussion here is on service rights, a consideration of these measures is outside the scope of this article. Instead, the special protections which might be available during the investigation stage will be discussed.

Article 23(2) provides that, during criminal investigations, the following measures shall be available to victims who are identified as having specific protection needs:

(a) interviews with the victim being carried out in premises designed or adapted for that purpose;

(b) interviews with the victim being carried out by or through professionals trained for that purpose;

(c) all interviews with the victim being conducted by the same persons unless this is contrary to the good administration of justice;

(d) all interviews with victims of sexual violence, gender-based violence or violence in close relationships, unless conducted by a prosecutor or judge, being conducted by a person of the same sex as the victim, if the victim so wishes, provided that the course of the criminal proceedings will not be prejudiced.

These are important protections to avoid victims being further traumatised during the investigation stage. In Ireland, commitments to offer these protections have already been made by the Gardaí. For example, the Victims Charter guarantees that sexual offence victims will be assigned a Garda of the same gender for the investigation of the offence and, as far as possible, a doctor of the same gender will also be provided for examination purposes. ${ }^{80}$ The Gardaí also provide specialist interviewers who are trained to interview children under 14 years of age and persons with an intellectual disability who are making complaints in relation to sexual crime, or offences involving violence or threats of violence. ${ }^{81}$ These specialist interviewers can also interview victims of sexual crime or serious crime or witnesses to those crimes where they are directed to do so. ${ }^{82}$ These interviewers will interview children and persons with intellectual disability in plain clothes 'unless the circumstances dictate otherwise'. ${ }^{83}$ Further, there are 'dedicated interview suites' in various locations which are designed to provide appropriate facilities for interviewing vulnerable witnesses and children. ${ }^{84}$ These suites are located away from Garda stations and may also be used for interviewing complainants of other serious crimes when this is appropriate. ${ }^{85}$

The Act introduces victim assessments as per the Directive's guidelines. Section 15(1) provides for assessments of victims for the purpose of:

79 Article 23(3). Special measures to assist victims in giving evidence were introduced into Irish law via the Criminal Evidence Act 1992. These include: giving evidence via television link (s 13); use of an intermediary (s 14); and the use of video-recorded evidence (s 16). Once the relevant Part of the Criminal Law (Sexual Offences) Act 2017 is commenced, it will also be possible for victims to give evidence from behind a screen.

80 Victims of Crime Office, Victims Charter (Department of Justice, Equality and Law Reform 2010) 17. Details of relevant support agencies will also be provided to these victims: ibid.

81 An Garda Síochána, Garda Siochána Policy on the Investigation of Sexual Crimes against Children, Child Welfare (2nd edn, An Garda Siochana 2013). Available at: www.garda.ie/Documents/User/Policy $\% 20$ on $\% 20$ the $\% 20$ Investigation $\% 20$ of $\% 20$ Sexual $\% 20$ Crime $\% 20$ Crimes $\% 20$ Against $\% 20$ Children $\% 20$ and $\%$ 20Child $\% 20$ Welfare $\% 202014 \% 2002 \% 2024 \% 20 \mathrm{HQ} \% 20 \mathrm{Dir} \% 2048 \% 2013$.pdf.

82 Ibid.

83 Ibid 72 .

84 Ibid.

85 Ibid 73 . 
(a) identifying the protection needs, if any, of the victim,

(b) ascertaining whether and to what extent the victim might benefit from protection measures, and

(c) ascertaining whether and to what extent the victim might, due to his or her particular vulnerability to secondary and repeat victimisation, intimidation and retaliation, benefit from

(i) special measures during the course of an investigation of the alleged offence, and

(ii) special measures during the course of any criminal proceedings relating to the alleged offence.

These assessments are to be carried out by the Garda Síochána or an officer of the Garda Síochána Ombudsman Commission who, when carrying out an assessment, will have regard to the following matters:

(a) the type and nature of the alleged offence;

(b) the circumstances of the commission of the alleged offence;

(c) whether the victim has suffered considerable harm due to the severity of the alleged offence;

(d) the personal circumstances of the victim, including his or her age, gender, gender identity or expression, ethnicity, race, religion, sexual orientation, health, disability, communication difficulties, relationship to, or dependence on, the alleged offender and any previous experience of crime;

(e) whether the alleged offence appears to have been committed with a bias or discriminatory motive, which may be related to the personal characteristics of the victim, including such characteristics as are referred to in paragraph (d);

(f) the particular vulnerability of victims of terrorism, organised crime, human trafficking, gender-based violence, violence in a close relationship, sexual violence or exploitation and victims with disabilities. ${ }^{86}$

The views of the victim will also be taken into account. ${ }^{87}$ If a victim is judged to have special protection needs, special measures will be made available to him/her both during the investigation and the trial. ${ }^{88}$ The special measures which may be implemented during the course of an investigation include:

(a) that any interview with the victim-

(i) be carried out in premises designed or adapted for that purpose,

(ii) be carried out by or through persons who have been trained for that purpose, and

(iii) where there is more than one interview, be carried out, where possible, by the same member or members of the Garda Síochána or the same officer or officers of the Ombudsman Commission, as the case may be;

(b) where the alleged offence involves sexual violence, gender-based violence or violence in a close relationship, that the victim be informed of his or her right to request that interviews are carried out by a person of the same sex as him or her. ${ }^{89}$

86 S 15(2). It should be noted that a child victim will be presumed to have special protection needs: s 15(7).

$87 \mathrm{~S} 15(4)$

88 Special measures available during the trial include the potential to exclude the public from the courtroom, limiting questioning about the victim's private life and extension of the availability of special measures for giving evidence under the Criminal Evidence Act 1992 (e.g. giving evidence by TV link): s 19. As explained already, discussion of these special measures is outside the scope of this article.

89 S 17(1). 
Such special measures must be made available unless:

(a) legal, operational or practical constraints render it impossible to do so,

(b) during the course of an investigation of an alleged offence by the Garda Síochána or the Ombudsman Commission, as the case may be, there is an urgent need to interview the victim and there are reasonable grounds for believing that a failure to do so may result in harm to the victim or another person,

(c) the application of a special measure would be prejudicial to a criminal investigation or criminal proceedings, or

(d) the application of the special measure would be otherwise contrary to the administration of justice. ${ }^{90}$

The protections in the Act replicate existing protections offered by the Gardaí. However, as victims now have a legal entitlement to these protections, they must be made available to them. This will necessarily impact upon resources and operating procedures as the Gardai must ensure that these protections are available. However, given the various limitations on these rights which are included in the Act, there appears to be some latitude to permit derogation from these protections where necessary. It is to be hoped that these limitations will be strictly interpreted and that victims will not be denied access to these protections lightly.

\section{Making the Directive's objectives a reality in Ireland: practical challenges}

The specific obligations which are imposed on Ireland in relation to service rights as a result of the Directive have been outlined in detail above. It is clear that realising the Directive's goals will give rise to a number of specific challenges and require criminal justice stakeholders to rethink their practices in significant ways. However, aside from the specific challenges faced in effectively delivering services under each of the key headings here, there are also a number of general, overarching practical challenges posed by effective implementation of the Directive and these must also be tackled if the goal of complete and effective service provision for victims of crime is to be met in Ireland.

\section{Unified service provision}

The fragmented nature of the response system available to victims in Ireland causes difficulties for victims, adding stress at a time when they are already vulnerable. Research has highlighted the difficulty victims experience in identifying and accessing the range of services which exist, often due to a lack of co-operation between the statutory and nonstatutory agencies working in the field:

... [o]verall the lack of a joined up approach is a major difficulty. To affect change individual women still rely on individual responses - e.g. by the Gardaí, by a Judge, by a housing officer, by a social worker. Supporting infrastructure and leadership needs to be developed as to how agencies all interact to help make victims safer (Women's Aid), ${ }^{91}$

Efforts have been made between agencies to encourage co-operation amongst key stakeholders in recent years, including, for example, the memoranda of understanding settled between the Office of the DPP and service providers and the appointment of a Detective Inspector Domestic Violence and Sexual Assault Investigation Unit as national liaison between An Garda Síochána and the NGO Sector. A strategy to encourage closer

90 S 17(2).

91 Eimear Spain, Sarah Gibbons and Shane Kilcommins, Analysis of Text for the Final Review of the National Strategy on Domestic, Sexual and Gender Based Violence, 2010-2014 (COSC 2014) 22. 
working relationships amongst key stakeholders in the field to ensure co-ordinated and effective referrals between support organisations will be important in coming years to ensure an improved experience for victims. ${ }^{92}$

\section{Training}

It is clear from the preceding discussion that a multi-pronged approach to minimise the potential for further traumatisation of victims in this jurisdiction is necessary, including the provision of appropriate facilities in all courtrooms and better communication with victims at all stages of the process. Key to this effort is the training and education of all frontline staff on the rights and needs of victims and the services available to them, thereby ensuring the rights of the victim move from rhetoric to reality. Article 25 specifically requests both general and specific training for police officers, court staff, judges, prosecutors, lawyers, and victim support and restorative justice organisations, with the form and scope of training varying depending on the duties of the cohort and nature and level of contact. Ultimately, the 'training shall aim to enable the practitioner to recognise victims and to treat them in a respectful, professional and non-discriminatory manner. ${ }^{93}$ That training to tackle a lack of sensitivity amongst criminal justice agencies and actors in this jurisdiction is necessary is clear ${ }^{94}$ and should aim to do more than inform service providers of their obligations. Rather, it should provide them with supports they need to provide victims with the sensitive approach mandated under the Directive. The Fundamental Rights Agency has highlighted that 'to be effective, training needs to cover both the need for a sensitive approach to victims, especially regarding particularly vulnerable groups such as child victims, and specialised knowledge, again with an emphasis on certain groups of victims. ${ }^{95}$ The coming years should see all organisations involved in the provision of services to victims implement a training needs assessment and a systematic training plan. While the emphasis will undoubtedly be on key frontline service providers such as the Garda Síochána, all organisations and agencies with whom victims interact including healthcare services, social services, victim support groups and legal professionals should engage with this process. ${ }^{96}$

\section{Quality assurance and monitoring}

The absence of formal processes to monitor the quality of services provided to victims of crime in Ireland has been the subject of criticism. ${ }^{97}$ The importance of 'clear and consistent quality control mechanisms' 98 has been emphasised by the Fundamental Rights Agency which notes that it is the 'responsibility of EU Member States . . . to monitor support services' performance, ensuring that they conform to designated standards while also respecting the independence of civil society'. ${ }^{99}$ The adoption of a system of quality control for victim support services, including key performance indicators and benchmarks, would enable transparent assessment of services and encourage remedial

92 EU Agency for Fundamental Rights (n 9) 14.

93 Article 25.

94 Mulkerrins (n 70); Lucia Zedner, Criminal Justice (OUP 2004); D Parkinson, 'Supporting Victims through the Legal Process: The Role of Sexual Assault Service Providers' (2010) 8 Australian Institute of Family Studies; Eimear Spain, Sarah Gibbons and Shane Kilcommins, Analysis of Text for the Final Review of the National Strategy on Domestic, Sexual and Gender Based Violence, 2010-2014 (COSC 2014) 14; Garda Inspectorate (n 14) 335-6.

95 EU Agency for Fundamental Rights (n 9) 51.

96 Ibid.

97 For example, Garda Inspectorate (n 14) 20.

98 EU Agency for Fundamental Rights (n 9) 14.

99 Ibid. 
action and consequential improvements in services, ultimately ensuring access to rights in practice. The importance of this process is underscored by Article 28 which requires member states to provide the European Commission with available data on how victims have accessed the rights established in the Victims' Directive on a three-yearly basis, beginning in November 2017. As part of this process, it will be necessary to address the deficiencies in the recorded crime data in Ireland. ${ }^{100}$ While important, it is suggested that an over-reliance on official crime statistics should be avoided and efforts to gain a holistic understanding of the experience of victims, including those who do not report to official authorities, should be made, particularly though the use of victims' surveys. ${ }^{101}$

\section{Resources}

It is clear from the preceding discussion that, if victims of crime and their families are to have access to justice, adequate information and services in practice, rather than simply in theory, then significant investment in the sector will be required. ${ }^{102}$ The difficulties for victims and support services in Ireland, both statutory and non-statutory, resulting from inadequate resourcing has long been recognised. ${ }^{103}$ Funding will be required to provide all the services outlined in the preceding discussion, including for: training; data collection and quality assurance; investment in personnel to provide services to all victims irrespective of whether the crime has been reported; and capital investment. It is therefore surprising that the Regulatory Impact Analysis of the General Scheme of the Victims of Crime Bill, which aims to transpose the Directive, ${ }^{104}$ indicates that 'it is likely that [the costs of implementation] . . . can be met from within existing resources'.105 Despite this rhetoric, some increase in funding to the sector has been announced. ${ }^{106}$ The increase in funding announced in 2016 to COSC amounts to approximately $€ 12,500$ extra for each of the 40 organisations supported, while the Victims of Crime Office will have an extra $€ 6000$ available for each of the 50 victim support organisations for whom it has

100 Garda Inspectorate (n 4); Central Statistics Office, Review of the Quality of Crime Statistics (Central Statistics Office 2015); Central Statistics Office, Review of the Quality of Crime Statistics 2016 (Central Statistics Office 2016).

101 Mathew Hall, Victims and Policy Making: A Comparative Perspective (Willan 2010) 16; Pamela Davies, Peter Francis and Victor Jupp (eds), Victimisation Theory, Research and Policy (Palgrave 2004); Pamela Davies, Peter Francis and Chris Greer (eds), Victims Crime and Society (Sage 2007); Rape Crisis Network Ireland, RCNI National Rape Crisis Statistics (Rape Crisis Network Ireland 2014) 23.

102 EU Agency for Fundamental Rights (n 9) 12; E O’Malley-Dunlop, 'Press Release: The EU Directive on Victims Rights', 16 November 2015 <www.drcc.ie/2015/11/press-release-the-eu-directive-onvictims-rights>.

103 Mulkerrins (n 70). Bacik et al (n 76); D Duffy, A Better Deal: The Human Rights of Victims in the Criminal Justice System (Irish Council of Civil Liberties (2008)); Grozdanova and de Londras (n 56).

104 'Criminal Justice Victims of Crime Bill' <www.justice.ie/en/JELR/Pages/Criminal_Justice_ (Victims_of_Crime)_Bill>.

105 'General Scheme of Criminal Justice (Victims of Crime) Bill Regulatory Impact Analysis' <www.justice.ie/en/JELR/Criminal\%20Justice \%20Regulatory $\% 20$ Impact $\% 20$ Analysis.pdf/Files/Criminal $\%$ 20Justice $\% 20$ Regulatory $\% 20$ Impact $\% 20$ Analysis.pdf $>$.

106 Press release: 'Fitzgerald Announces 600 New Gardaí to be Recruited in 2016' <www.justice.ie/en/JELR/Pages/PR15000535>. 
responsibility. ${ }^{107}$ Given the significant under-resourcing of the sector to date, it is questionable whether these rather small increases in funding will be sufficient to meet increased demands under the Directive and to ensure adequate and effective access to services. The creation of new rights without adequate support or funding from central government creates frustration amongst service users, ${ }^{108}$ a frustration which is directed at individual services and criminal justice agencies. It is incumbent upon central government to adequately resource the agencies and services which are required to deliver upon the expectations of victims.

\section{Transposition of the Directive}

Concerns have also been raised about the proposed measures to transpose the Directive into Irish law, ${ }^{109}$ including whether the proposed implementation measures meet national obligations under the Directive. ${ }^{110}$ The narrow focus of the 2017 Act, which focuses exclusively on the right to information (Part 2) and the protection of victims during investigations and criminal proceedings (Part 3) and limits its reach to victims who engage with the Garda Síochána or the Garda Síochána Ombudsman Commission, is to be lamented. While s 7(9) of the Act provides that a member of the Garda Síochána or an officer of the Ombudsman Commission may arrange for the victim to be referred to a victim support service with their consent, the obligation is limited to these organisations. This is not reflective of Article 8 of the Victim's Directive under which the obligation to facilitate referrals of victims to victim support services applies to both competent authorities and 'other relevant entities' which include 'public agencies or entities, such as hospitals, schools, embassies, consulates, welfare or employment services, who are in contact with victims and identify the need for the victim to seek the specialised services of a VSO'. ${ }^{111}$ It is also unfortunate that wider rights given under the Directive are not accommodated within the Act, for example, the right to access support services mentioned

107 Victims' Rights Alliance, 'Budget 2016 21\% Increase in Funding for Victims of Crime Office. This Amounts to an Increase of $€ 300,000$ for 50 victim support organisations, $€ 6,000$ each' https://victimsrightsalliance.com/2015/10/14/budget2016-21-increase-in-funding-for-victims-of-crimeoffice-this-amounts-to-an-increase-of-e300000-for-50-victim-support-organisations-e6000-each>. A further $€ 250,000$ in funding for the Victims of Crime Office was announced for 2017 <www.justice.ie/en/JELR/Pages/PR16000311>. €600,000 in funding was also announced for COSC and Victims of Crime to facilitate an awareness-raising campaign on domestic and sexual violence and to fund domestic violence perpetrator programmes required under the Council of Europe Convention on Preventing and Combating Violence against Women and Domestic Violence: 'Tánaiste Welcomes Extra Funding for Garda Recruits, More Civilian Staff and Sustained Additional Overtime in 2017' $<$ https://merrionstreet.ie/MerrionStreet/en/News-Room/Releases/Tanaiste_welcomes_extra_funding_ for_Garda_recruits_more_civilian_staff_and_sustained_additional_overtime_in_2017.html\#sthash.jKJ1Ppxl .dpuf $>$.

108 Brian Williams, 'The Victim's Charter: Citizens as Consumers of Criminal Justice Services' (2009) 38 Howard Journal of Criminal Justice 384, 391.

109 Shane Kilcommins, Susan Leahy, Kathleen Moore Walsh, Eimear Spain, The Victim in the Irish Criminal Process (Manchester University Press 2017).

110 Several Bills have been published, including the Domestic Violence Bill 2017 and the Criminal Law (Sexual Offences) Act 2017, which supplement existing legislation and fulfil some of our obligations under the Victims Directive. However, the primary piece of legislation in this regard is the 2017 Act, the long title of which identifies it as 'an act to give effect to provisions of Directive 2012/29/EU . . establishing minimum standards on the rights, support and protection of victims of crime'.

111 European Commission, DG Justice, Guidance Document Related to the Transposition and Implementation of Directive 2012/29/EU of the European Parliament and of the Council of 25 October 2012 establishing minimum standards on the rights, support and protection of victims of crime, and replacing Council Framework Decision 2001/220/JHA (2013) 25. 
above or the broad rights to information, advice, support, referral, and emotional and psychological support, where available, under Article 9 of the Directive.

\section{Conclusion}

The opportunity to improve the experience of victims of crime in Ireland presented by the momentum associated with the Victims' Directive is welcome and this article has highlighted the many positive developments and practices in recent years, while cognisant of the many challenges posed in delivery effective services to victims. Given the broad rights to information, support and protection afforded to victims under the Directive, stakeholders will be required to re-examine the nature of their engagements with victims in the coming years and recognise them as bearers of rights rather than mere 'consumers of criminal justice'. ${ }^{112}$ While victims have become a focus of political and societal concern ${ }^{113}$ and strides have been made to improve their experience in the criminal justice system, the article has highlighted serious deficits and significant investment in service provision, research, training and education is required. Efforts must also be made to address the systemic problems which impact on victims of crime, particularly those affecting rates of reporting and attrition. The responsibility rests with the state to move from the rhetoric of legal and service rights to a reality where victims of crime are respected, accommodated and provided for in this jurisdiction. 